\title{
Older People and HIV Infection: An Experience of "Ageing Badly" Within the City of Abidjan (Côte D'Ivoire)
}

\author{
Ahou Clémentine Say TANOH \\ Sociology Department, Félix Houphouët-Boigny University (UFHB), 23 B.P.126 Abidjan 23, Côte d’Ivoire.
}

\begin{abstract}
In Côte d'Ivoire, active ageing remains a worrying and topical subject which requires cross-sectional studies. The present study is a contribution to this reflection with a particular focus on the "ageing problem" in relation to HIV infection. In a qualitative approach, individual semi-directive interviews were conducted with 23 people aged between 60 and 67 years, including 17 women and 6 men infected with HIV. They are members of a NonGovernmental Organization (NGO) that provides assistance to people living with HIV (PLHIV). These respondents were selected for the study on a voluntary basis, based on availability and defined criteria. The interviews took place at the headquarters of this NGO over a discontinuous period from 26 April to 13 June 2021. The thematic analysis of the content of the speeches brought out the social representations of HIV/AIDS and of "ageing badly" among the respondents. The latter represent HIV/AIDS as "the disease of people with a bad lifestyle. They would have contracted it through a "spell" that would have been cast on them. They perceive being HIVpositive in old age and chronic geriatric illnesses as an expression of 'bad age'. Unprotected sex with multiple partners, infidelity within the couple and, indirectly, the use of aphrodisiacs are the risk factors that exposed them to the virus. HIV combined with underlying chronic illnesses has contributed to their fragility, social vulnerability and dependence. As they are victims of social rejection and stigmatization by their respective family members, the inclusion of older people living with HIV (PLWHA) in HIV/AIDS programs is essential. Similarly, sexuality education for older people is useful. It is therefore more than urgent to organize public solidarity around PLWHA in Côte d'Ivoire.
\end{abstract}

Keywords: Older people, HIV, "Ageing badly", Côte d'Ivoire.

DOI: $10.7176 /$ RHSS/11-22-06

Publication date: November $30^{\text {th }} 2021$

\section{Introduction}

Countries with large ageing populations need to think about healthy ageing or successful ageing or "ageing well". Growing old with HIV is one of the major challenges facing all continents today, especially Africa. Indeed, $83 \%$ of AIDS-related deaths worldwide were recorded in sub-Saharan Africa (WHO, 2016). Côte d'Ivoire is not on the fringe of this health reality, especially in terms of the elderly. According to the CIPHIA ${ }^{1}$ study, out of a total population of approximately 390,000 people living with HIV (PLHIV) aged 15-64 years, HIV prevalence among people aged 60-64 years in Côte d'Ivoire is 8.5\% among women and 6.0\% among men. This prevalence is higher among women than among men. Yet, the study shows that Côte d'Ivoire is committed to reducing this prevalence through a multisectoral and decentralized approach to HIV/AIDS patients.

Moreover, according to the same study, the Ivorian government, through the Ministry of Health and Public Hygiene, has made voluntary testing and ARV treatment accessible and free throughout the country since August 2008. However, very little data is available on HIV/AIDS epidemiology among the elderly, whose demographic growth is increasingly obvious in Côte d'Ivoire. According to estimates by the National Institute of Statistics (NIS) in 2014, the number of people aged 60 or over is expected to reach 1,200,000 for a general population of 25,195,540 in 2018, compared to 913,668 in 2014 for 22,671,331 inhabitants (NIS, 2014).

Within this elderly category of the population, many experience pathological ageing with physical and/or psychological impairment (Morée, 2018). Indeed, empirical findings point to chronic geriatric pathologies that make some of them vulnerable, fragile and dependent. As if this were not enough, in addition to these chronic pathologies, these elderly people are also infected and affected by HIV. This situation contributes to making any positive perspective of healthy ageing negative (Aquino et al., 2016) and to offering instead any alternative of " ageing badly". What reflection can therefore be carried out on "ageing badly" in a context of HIV infection in Côte d'Ivoire?

According to Lebouché et al (2008), three profiles of people ageing with HIV can be distinguished: those who have been living with the infection for many years, also known as "survivors"; those who have been newly diagnosed; and those who were infected at an advanced age.

The present study takes into account these three profiles of older people infected with HIV.

It is intended to contribute to the discussion of "ageing badly" through the situation of older people infected with

${ }^{1}$ COTE D'IVOIRE POPULATION-BASED HIV IMPACT ASSESSMENT. Under the aegis of the Ministry of Health and Public Hygiene, Côte d'Ivoire Population-based HIV Impact Assessment (CIPHIA) study released its results on 17 April 2018. 
HIV. On the other hand, the concept of "ageing well" points towards a positive perception of ageing, the prevention of problems associated with old age and an "opportunity to move towards innovative actions for the prevention of dependency» Beudet et al (2011, p.11). As perceived, "ageing well" seems to elude the older people in the target group of this study, who experience "ageing badly" instead. How do they view HIV/AIDS and 'ageing badly'? This study is based on the theory of social representations, which "is the product and process of a mental activity by which an individual or a group reconstitutes the reality with which it is confronted and attributes a specific meaning to it" (Abric, 2016). In this sense, HIV/AIDS and 'ageing badly' refer to a meaning, a representation that needs to be identified for these older people.

\section{Materials and methods}

The idea for the study arose from a reunion with a former acquaintance of about 63 years of age who had contracted HIV in her fortieth year. I was very curious to know that he was still alive, after having lost touch with him for over ten years. During our interactions, it turned out that he runs a non-governmental organization (NGO) in the district of Yopougon that supports people living with HIV (PLHIV) who are victims of rejection and stigmatization. Among these are many people aged 60 or over who, being indigent or victims of rejection and stigmatization, live at the expense of this NGO. There are several perceived reasons for choosing these older people as the target population for the study. First, they are rejected and stigmatized because of HIV, which is a sexually transmitted infection. Second, they are victims of stereotypes related to the sexuality of older people. Third, they are more vulnerable because of their ageing and chronic illnesses. Finally, they live in a context of economic destitution. The mission of this NGO is to assist PLHIV who are victims of rejection and stigmatization. It has 750 members, all living with HIV. Their ages range from 12 to 69. The NGO facilitates their access to antiretroviral therapy, as well as adequate treatment in case of opportunistic diseases. The sample for the study was therefore drawn from the NGO's records. The records include all the beneficiaries of the NGO's services from its inception in 2002 until 26 April 2021, the date of the beginning of the present study.

However, only 23 out of 71 people aged between 60 and 67, including 17 women and 6 men, agreed to participate in the study. The latter were therefore selected for the study on a voluntary basis, based on their availability and the technique of reasoned choice, according to the above-mentioned criteria. In order to remain anonymous and discreet, some of them refused to take part in the study. The same applies to all those who were travelling at the time of the survey.

A qualitative approach was therefore used to carry out this study. Individual semi-directed interviews were conducted with the 23 older actors at the NGO's headquarters over a discontinuous period, from 26 April to 13 June 2021. The interview guide was built around the following points: the representations of HIV and "ageing badly" among the elderly interviewed, the risk factors that led to HIV and the impact of HIV on the target group of the study

The interviews were recorded using a digital Dictaphone (Sony ICD-P520 IC recorder), after obtaining verbal consent from the respondents. Thematic content analysis was chosen as the technique for analyzing the discourse produced by the respondents during the interviews. The interviews were transcribed and 23 records were compiled and then analyzed across the board. They were grouped by theme. From the corpus obtained, the coding was done. Analytical categories were constructed. The units of meaning and finally the main ideas were the last stage of the process.

\section{Results}

The results of this study are structured as follows:

- The social representation of HIV/AIDS and of the "bad old-getting";

- $\quad$ The risk factors that led to HIV;

- The impacts of HIV upon old people.

\subsection{The social representations of HIV/AIDS and of the "bad old-getting";}

\subsubsection{The social representations of HIV/AIDS}

The representations that elderly people have about HIV are functions of their level of knowledge of the virus. Moreover, the quasi-totality of old people had already heard about HIV/AIDS. To the question to know what represents AIDS for them, their answers seem to converge:

"AIDS, I know it well! It's this disease that arrived in the United States and started to kill homosexuals first. After, it took the whole planet and killed everywhere in the world up to Africa and Ivory Coast. This is the disease of the homosexuals, prostitutes and people who live wrong. But for others as us, we don't know why we caught it. Me, I know that someone cast me a spell with AIDS". (G.R., man of 62 years old)

"Me, I have never thought that one day, I would catch AIDS in my age! And I would end my life 
with HIV. I have always thought that it was the illness of youngsters who stroll everywhere. But unfortunately, I caught the virus with the first man who asked me for marriage and for 15 years, I am HIV-positive." (K.H., woman of 64 years old).

According to these sixty-years-old people, AIDS is a disease of people of bad lives like homosexuals, prostitutes and debauched persons. According to the perception of mister G.R (62 years old), it is by the means of a bad spell he was cast that he contracted the virus. The representations of the respondents of HIV expose their ignorance about the virus, its transmission ways and the means of prevention. One can easily understand why they have been infected by the virus to which they probably exposed themselves through some risky behaviors.

\subsubsection{The social representation of the "bad old-getting"}

The "bad old-getting", a concept socially and culturally constructed is diversely represented by old people living with AIDS (OPLHIV). These various representations appear inside the discourses of the investigated persons. Thus, the "bad old-getting" is represented as "being HIV-positive at an advanced age"; "being affected by incurable diseases in old age."

\subsubsection{HIV-positivity in old age, a spot of the "bad old-getting"}

Old people questioned, compare HIV-positivity in an advanced age to "bad old-getting". They perceive their case as irreversible. They deplore their life end with HIV from which they cannot be healed. Then, it is by a great affliction they express themselves in the following words:

"We, do not know what to do anymore. In our age, this incurable disease is stuck to us and we must live with it until the end of our lives. We don't have any other solutions apart from that. This is it the "bad old-getting". Live with HIV being old. Who can understand you to say that one will take pity on you? It is humiliating, all that!" (T.I., woman of 66 years old)

In short, the "bad old-getting", for some, is part of HIV, the dishonor and an unhappy end of life. HIV as being sexually transmitted, live with this virus in an old age is the symbol of an immoral life and a shame for those respondents. For others the "bad old-getting" appears with the chronic diseases.

\subsubsection{The geriatric chronic diseases, expression of the "bad old-getting"}

The chronic diseases are some long-life affections which generally develop in a slow way. The chronic diseases (heart diseases, cerebral vascular accidents, cancer, chronic lung affections, diabetes) are the very first cause of death in old people mainly. In this study, they are identified as distinctive signs of the "bad old-getting" by the investigated persons. That is what they express as follows:

"The bad old-getting, it's when at 60 years' diseases like the cancer of prostate, glaucoma, diabetes, hypertension with CVA (Cerebral Vascular Accidents) overwhelm you. And as if it was not enough, for us, AIDS comes to admix." (K.B., man of 65 years)

This category of OPLHIV highlights the biological aspect of ageing that results in the sum of the anatomic, histological and physiological alterations, arisen in the course of time inside the different cells types, in their different organs and systems. Cancers, eye affections, high blood pressure and diabetes combined with AIDS have widely been mentioned by several investigated persons as some chronic pathologies which determine their "bad old-getting”. Some risk factors have also been talked.

\subsection{The risk factors that led to HIV}

The risk factors that exposed old people to HIV are the same as those of the other age groups. They encompass the risky behaviors such as the non-protected sexual contacts, multiple partners, infidelity in the couple and indirectly the usage of aphrodisiac products. The different avowals of the investigated persons highlight the question:

"In Yopougon, the aphrodisiac products are sold everywhere and we are supplied easily. When you use these products, you become real man with high performance! So, to fulfil my need, I confess that I so much went to prostitutes regularly. I also had many girl mates and since I don't like condoms too much, I caught the virus for 12 years. What happened to me is my fault and today I regret a lot." (A.K., man of 67 years old)

Sexuality with old people sometimes remains a taboo topic and sacred during the sensitization campaign on the Sexually Transmitted Infections (STI) and HIV/AIDS. This sensitization is generally directed towards youngsters recognized as sexually active. Meanwhile, the old people by thinking to be sheltered from these pathologies presented some high risky behaviors. In fact, these people in their ignorance and doubtlessness have multiplied occasional partners without any protection being under the effect of some aphrodisiac products. As drawbacks, they infected themselves to HIV leading them to a pathological old-looking until the "bad old-getting".

\subsection{The impacts of HIV and the "bad old-getting" upon old people}

From the senescence, certain chronic pathologies which old people are suffering from provoke their fragility. HIV associated with those underlying chronic diseases helps reinforce their vulnerability and negatively impact their life. 
According to the investigated people, the impacts of HIV are at diverse levels that is worth exploring:

"In the beginning of the disease that has been starting for 6 years, I was not seeing well anymore and everything was blurred in front of me. After, I was in a continuous depression, the disease was growing until it was found that I got AIDS. It is true that we are given medicines at the NGO, but I am still suffering from eye disease. Moreover, I am no longer in a good health. Every day I feel bad anywhere in my body and I suffer a lot in it." (L.M., woman of 63 years old)

As counted in that saying, the precarious health of this woman is linked to HIV she contracted 6 years ago. The cognitive aims, functioning with functional and cognitive deficiency, mental depression and eye affections are some impacts of HIV on this sixty-years-old woman. Moreover, the OPLHIV are all victims of rejection and stigmatization from the members of their respective families. That is what legitimates their presence in this NGO which mission is to accompany the OPLHIV victims of rejection and stigmatization due to HIV. The following saying charged with emotions gives us much more understanding on the question:

"There is no worse suffering than what I am actually living now. When I married a second spouse, my wife got angry and went back to her family with our five children. I tried to beg her pardon, but she refused and her parents got me out. I didn't know that the second wife was sick. She infected me with AIDS and she died after. I remained alone apart from the help of the lady's NGO. My own relatives fell out with me and since they knew that I caught AIDS, nobody comes to me anymore. My end of life is sad, so sad for me; that is not a god old-getting." (T.Y., man of 67 years old).

As counted, T.Y., (67 years old) and others make the experience of a physical and social decline which led them more and more to the solitude. As being object of rejection and stigmatization from his, this respondent associates his demeaning and negative image, the "bad old-getting" that he assimilates to a sad end of life that is so sad. In this context, the OPLHIV are socially isolated with a limited access to relatives' assistance. That is what justifies their membership to this NGO of charity close to it they find psychological, spiritual, hygienic and material supports.

\section{Discussion of the results}

The results have shown the social representations of HIV / AIDS and 'bad aging' among the HIV aged persons (HIVAP), the risk factors that led them to HIV and the impacts of HIV on them. From the analysis of these results, three essential points come out in the chapter of the discussion: the need to integrate the elderly in the fighting programs against HIV / AIDS, the usefulness of sexuality education among elderly people, the emergency of public solidarity around HIVAP in Côte d'Ivoire.

\subsection{The need to integrate the elderly in the fighting programs against HIV / AIDS}

In Côte d'Ivoire, the HIV sensitization campaigns generally target young people and adults. The older people are often overlooked during these campaigns because of the prejudices according to which young people and adults are more sexually active than old people. The HIV infection through sexual practices among the elderly therefore contributes to the deconstruction of ideologies, beliefs and discourse related to the sexuality of these people. Indeed, the senescence with its corollary of chronic pathologies is also characterized by the sum of the anatomical, histological, physiological and cognitive alterations, which occurred over time, within the different cell types, in the different organs and systems of the individual. (Bourdelais, 1994). This finitude of the body often induces in other social categories negative representations of the old people and prejudices which destroy the practice of sexual relations among the elderly. Therefore, old age does not exclude sexuality. Rather, it continues to be performed within the limits of the physiological capacities of aged actors. And, when their capacities are affected by various factors, old people resort to other uses such as aphrodisiacs in an attempt to improve their sexual performance. As consequences, they become "stacked, performant boys", according to themselves. And, to satisfy their libido, some of them resort to prostitutes and other multiple partners. By reorganizing their life to satisfy their sexual need, they are exposed to the AIDS virus, in view of their insufficient knowledge of this virus and of the ways of transmission: "Le sida, ...c'est la maladie des homosexuels, des prostitués et des gens qui vivent mal. Mais nous autres, on ne sait pas pourquoi on l'a attrapé? Moi, je sais qu'on m'a lancé un sort avec sida. » (G.R., homme de 62 ans) ${ }^{1}$

In this context, therefore, the results of the present study go in line with J-C's theory of social representations. Abric (2016). In fact, the representations that these elderly people have of HIV / AIDS are presented as the product and the process of a mental activity by which this target group reconstitutes the reality (AIDS) with which it is confronted and attributes a specific meaning to it. (Abric, 2016) “... I have been cursed with AIDS". The pleasure linked to sexuality being not only the exclusivity of young people and adults, the sensitization programs on HIV / AIDS and other Sexually Transmitted Infections (STI) must integrate the elderly (Lebouché et al., 2008). Their

\footnotetext{
1 “AIDS is the disease of homosexuals, of prostitutes. and people who live badly. But we don't know why we caught it? I know that I have been cursed with AIDS. (G.R., 62-year-old man).
} 
inclusion in these different programs (Billette et al., 2012) responds to the major challenges of a society of all ages ( Guillemard and. Mascova, 2017).

\subsection{Usefulness of sexuality education for the elderly in Côte d'Ivoire}

The issue of older people's sexuality has often been overlooked in social debates and programs in Côte d'Ivoire, and researches in the same line are practically nonexistent. Therefore, according to Ribes and Cour (2013), with age, sexuality persists without ever completely disappearing, even if in its genital dimension, it becomes less and less frequent. This issue is however topical due to the increase in life expectancy, with maintenance of physical and mental capacities (Ribes, Cour, 2013). The sexuality of older people has often been a taboo subject for some (Dupras, 2010). For others, on the other hand, it is opinions, attitudes and practices relating to the sexuality of older people that socially disqualify older people (Trivalle, 2006). This is the case with the family and especially with children who find it difficult to accept their parents' sexuality. Considering this sexuality refers them to their own sexuality and, moreover, to their own aging process (Trivalle, 2006). This process of social disqualification and social disapproval of seniors in relation to their sexuality accounts for ageism. In such a context, some old people practice their sexuality discreetly, while ignoring the risk factors associated with infections: “... to have my pleasure, I admit that I frequented prostitutes a lot. I also had girlfriends and since I don't really like condoms, I caught the virus 12 years ago ..." (A.K., Male, 67). They leave themselves exposed to Sexually Transmitted Infections (STI) and HIV / AIDS and they go underground. Therefore, HIV testing in this age group is often underestimated because of stereotypes related to the sexuality of the elderly. As a consequence, once infected, these elders are poorly perceived by society because these STI and HIV are linked to sexuality. Elders' ignorance of the risk factors that expose them to HIV / AIDS can also be explained by the fact that, generally, they are excluded from sexuality education programs which seem to be the exclusive domain of categories of younger people. Education about sexuality among young people is based on teaching and learning of the cognitive, emotional, physical and social aspects of sexuality. This program could also be useful for seniors in Ivory Coast HIV / AIDS, by integrating and developing sexogerontagogy in order to enable them to benefit from sexuality education (Dupras \& Viens, 2008). It could equip older people with knowledge, skills, attitudes and values enabling them to enjoy their right to health, well-being and dignity. And as these authors argue, elders could get involved on the path of wisdom, without putting apart passion. In this context therefore, sexuality would no longer be perceived as degrading for the third age, but rather as being able to contribute to healthy aging.

\subsection{From the emergency of public solidarity around HIVAP in Côte d'Ivoire}

In Côte-d'Ivoire, we still observe a kind of silence, of ageism in a country where local cultures have valued the elderly by making them custodians of culture (Tanoh, 2014). With a sanitation system devoid of geriatrics, elderly patients, already vulnerable due to senescence (Amyot, 2019), undergo careful management of the various pathologies that attack them. Aging is a social construction and old age is built on a reality that includes elements of a biological, demographic, political, economic nature ... but it is also built on a cultural imaginary of representations (Abric, 2016). These representations are important in the social challenges of old age and in public policies supporting aging people.

Therefore, in this sense, the absence of geriatrics in the sanitation system testifies to a refusal to integrate the elderly at the heart of comprehensive global policies in Côte d'Ivoire (DAYORO, 2009). The vulnerability of elderly patients is also made favorable by low insurance coverage in Côte d'Ivoire. Indeed, apart from retired civil servants and private sector agents (representing $3.1 \%$ of the elderly population) (INS, 2014) who receive a retirement pension, the vast majority of elderly people $(6.99 \%)$ live only depending on their respective families (Tanoh, 2014). And when family solidarity weakens or becomes negative, the old person finds himself alone (Abdramane et al., 2013). This is what the HIVAP experience in this study: “... if it is not the NGO of the lady who supports us. My own parents got mad at me too, and since they found out I have AIDS, no one sees me anymore. My end is sad, very sad even and for me, that is not a good old age!" (T. Y., 67-year-old man). And as Thomas (2008) argues, vulnerability concerns the interactions of a person (elderly living with HIV in this study) with his social and human environment, insufficiently containing and over which he has little control (Thomas, 2008). Because of their social isolation, older people made vulnerable by HIV have little weight in social dialogue. people do not hear them because they hardly give them a voice.

The emergency of institutional or under state control solidarity coupled with that of the family is essential in the support of aging people (Rozez, 2020) and particularly HIVAP in Côte d'Ivoire. Because, it is in a social interaction between the macro social (institutions), meso social (associations) and micro social (family and friendly framework) level that, in a socio-historical context, the elderly will be able to experience successful aging.

\section{Conclusion}

HIV infection among the elderly is a reality in Côte d'Ivoire. The ideologies conveyed by society on the sexuality of the elderly induce great discretion among the elderly in their sexual practices. Also, facing the ethical issue, 
sexuality and the risk factors for HIV transmission are almost hidden with the elders during HIV sensitization campaigns. As a consequence, they expose themselves to HIV, which reinforces their state of vulnerability. Combined with senescence and the underlying chronic pathologies, HIV infection accentuates 'bad aging' to them. These generally evolve in a context of stigmatization, social marginalization and exclusion from public policies supporting aging people.

The present study is therefore intended to be a contribution to the reflection on 'bad aging' through the situation of elderly people infected with HIV. Achieving this goal required a qualitative approach. Semi-structured individual interviews were conducted with 23 people aged 60 to 67, including 17 women and 6 men, on the basis of voluntary work and availability to participate in the study and some defined criteria. The study took place over a discontinuous period, from April $26^{\text {th }}$ to June $13^{\text {th }}, 2021$, at the headquarters of the NGO supporting these people. At the end of these interviews, the social representations of HIV / AIDS and "bad aging" were determined. Respondents view HIV / AIDS as "the disease of people with a bad life, including homosexuals, prostitutes and debauched young people". In this sense, therefore, some admit to having contracted it through a curse that would have been cast on them. Their ignorance of HIV / AIDS in terms of its ways of transmission and the means of prevention has been proven. Moreover, they perceive HIV infection in old age and chronic geriatric diseases as expressions of "bad aging". Such representations can only lead to the risk factors that led these elderly actors to HIV. These are mainly risky behaviors such as unprotected sex with multiple partners, infidelity and, indirectly, sexual performance with the use of aphrodisiac products. HIV associated with underlying chronic diseases contributes to the vulnerability of old people and negatively impacts their lives. Indeed, the HIVAP surveyed are all victims of rejection, stigmatization and social isolation from members of their respective families. This is what justifies their membership in this NGO providing assistance to HIVAP from which they have found psychological, spiritual, health and material support.

In this context therefore, contrary to the social discourse revealed by Tanoh (2014) according to which the old people are valued in Africa and particularly in Côte d'Ivoire, the study rather highlighted the paradigm of decline which conveys a demeaning image of the elderly, here, infected with HIV. Their old age reflects the image of a physical and social decline that has led them to a life of dependence (Malcolm, 2001) on this NGO. Their old age is neither a moment of appreciation, nor a privileged and fascinating stage in life (LeFrançois, 2004). This is what justifies the scientific and social significance of this study. However, from a methodological point of view, the study has some limitations. Although it took into account the three profiles of old people infected with HIV (those living with the infection for many years, also called 'survivors'; those newly screened; those who were infected at an advanced age (Lebouché et al., 2008), it could, however, have included a greater number of HIVAP who evolve in other support structures. A comparative study of these people could better situate us on the issue of ageism, of social rejection and 'bad aging' with HIV. These points for further study are considered as the perspectives of this study.

Acknowledgements: My gratefulness goes to the manager of the non-governmental organization for VP HIV and her staff, who helped in the frame of data collection for this study.

I also thank older people living with HIV and who accepted to contribute to this study. Hopping to see their living conditions improved, they were motivated to grant a particular attention to this study.

Conflict of interest: as the author of this study, I show no conflict of interest related to it.

\section{References}

Abdramane, B., Berthe-Sanou, L., Konaté, B., Hien, H., Tou, F., Drabo, M., Badini-Kinda, F., Macq, J. (2013). Les personnes âgées en Afrique subsaharienne : une population vulnérable, trop souvent négligée dans les politiques publiques, Santé Publique 2013/3 (Vol. 25), pages 367 à 371.

Abric, J.-C. (2016). Pratiques sociales et représentations, Psychologie et Psychanalyse, Quadrige, $\mathrm{n}^{\circ} 2,312 \mathrm{P}$.

Amyot, J.-J., (2019). Entre idéologie et réalité. In : Eynard, C (Dir.) Les vieux sont-ils forcément fragiles et vulnérables ? Paris : Erès Editeur, Collection les nouvelles catégories de l'âge.

Aquino, J.-P., Barthelemy, L., Cudennec, T. (2016). Guide Pratique Du Vieillissement : 75 Fiches Pour La Pour La Préservation de l'Autonomie Par Les Professionnels de Santé. Elsevier Health Sciences, 440 pages. Repréré à htpps //: www. books.google.ci > books.

Beudet, A., Coppin, M., Hennebique, V., Labart, S., Leferbre, J., Le Nay, C., Pellegrino, N., Redon, C. \& Sauveplane, C. (2011). « Bien vieillir, prévention de la dépendance ? »-EHESP, mémoire EHESP de module interprofessionnel (MIP), 30+XXIX p.

Billette, V.., Lavoie, J.-P., Seguin, A.-M. et Pevenage, I. V. (2012). "Réflexions sur l'exclusion et l'inclusion sociale en lien avec le vieillissement. L'importance des enjeux de reconnaissance et de redistribution "), Frontières, vol. 25, n ${ }^{\circ}$ 1, p. 10-30 (DOI 10.7202/1018229ar, lire en ligne [archive])

Bourdelais, P. (1994). L’âge de la vieillesse. Histoire du vieillissement de la population. Editions : Odile Jacob, Paris, France. 
Dayoro, Z. A. K. (2009). Les conditions de vie des retraités, thèse de doctorat unique, université de Cocody, Abidjan, non publié.

Dupras, A. (2010). « La sexualité des aînés au cinéma : de l'enfer au $7^{\mathrm{e}}$ ciel 》, La revue francophone de gériatrie et de gérontologie, vol.17, $\mathrm{n}^{\circ} 162, \mathrm{p} .108-112$.

Dupras, A. \& Viens, M-J. (2008). «L'éducation à la sexualité des aînés : éléments de sexo-gérontagogie », Sexologies, vol. 17, n³, p.135-142.

Guillemard, A.-M. et Mascova, E. (dir) (2017). Allongement de la vie. Quels défis ? Quelles politiques ? Paris, La Découverte.

Institut National de la Statistique (INS) (2014). Recensement Général de la Population et de l'Habitat (RGPH) 2014. Principaux résultats, Abidjan.

Lebouche, B., Wallach, I. et Levy, J. J. (2008). Vieillir avec le VIH : enjeux éthiques autour d'une population invisible, Les enjeux éthiques du vieillissement, vol. 10, $\mathrm{n}^{\circ} 2$.

Lefrançois, R. (2004). Les nouvelles frontières de l'âge, Montréal, Presses de l'Université de Montréal, 357 pages.

Malcolm, J. (2001). La conception de la vieillesse dans les théories gérontologiques, in retraite et société, volume $\mathrm{n}^{\circ} 34$ PP 5.

Morée, H. (2018). Le vieillissement pathologique. Santé et forme. Disponible sur https://seniors-mag.com > actu > le-vieillissement-pathol.

Organisation Mondiale de la Santé (2016). Vieillissement et qualité de la vie dans Rapport mondial sur le vieillissement et la santé. Disponible sur https//: www.who.int > publications > world-report-2015.

Ossiri, Y. F., Tanoh, A. C. S. et Dayoro, Z. A. K. (2017). Représentation sociale de la retraite active : le cas des retraités affiliés au fonds international de la retraite active (FIDRA), Rev. ivoir. anthropol. sociol. KASA BYA $K A S A, \mathrm{n}^{\circ} 34,2017$ (C) EDUCI.

Ribes, G. \& Cour, F. (2013). La sexualité du couple âgé : état des lieux, prise en charge. Disponible sur https://www.urofrance.org > base-bibliographique > la-s...

Rozez, S. (2020). Politiques sociales de la vieillesse et de la longévité : recul de la solidarité nationale et réémergence des solidarités familiales, Revue des droits de l'homme, URL : http://journals.openedition.org/revdh/7692 ; DOI : https:// doi.org/10.4000/revdh.7692

Tanoh, A. C. S. (2014). Conditions de vie des personnes âgées chez les Tchaman en Côte d'Ivoire, Thèse de Doctorat en Sociologie, Institut d'Ethno Sociologie / Université Félix Houphouët Boigny d'Abidjan Cocody, non publié.

Thomas, P. (2008). "Vulnérabilité, fragilité, précarité, résilience, etc. De l'usage de la traduction de notion éponge en sciences de l'homme et de la vie". Esquisses, 13, 13-27.

Trivalle, C. (2006). « La sexualité du sujet âgé », NPG Neurologie, psychiatrie, gériatrie, vol. 6, no 31, p. 6. 